\title{
Research on Competition Training Based on Blended Learning
}

\author{
Jie Liu \\ Experiment Center \\ Guangzhou Uniersity \\ Guangzhou, China \\ 32919484@qq.com
}

\author{
Xiaoli Long \\ Experiment Center \\ Guangzhou Uniersity \\ Guangzhou, China \\ 454365137@qq.com
}

\begin{abstract}
Traditional courcing competition integration training can not change the situation of passive learning. Blended learning based on mobile learning is mainly based on students' self-study, which can realize students' personalized learning. Competition training based on blended learning is bound to change the learning state of students. A competion training mode based on blended learning is proposed, which is devided into three stages in this paper. According to task driven teaching, the training is designed with several tasks. This paper systematically discusses the theoretical basis of task driven teaching competition training based on blended learning, then describes the design and implementation. The trainning mode would make online learning more convenient and personalized, and make teaching and learning become normal, so that online and offline learning depth fused and personalized.
\end{abstract}

Keywords-Blended learning; Competition training; Task driven teaching; Mobile learning

\section{INTRODUCTION}

With the popularity of intelligent terminals, such as smart phones, laptops and tablet computers, more and more learning methods emerge. Mobile learning (M-learning for short) is a new learning model based on mobile learning terminal and network technology, which is emerged with the development of science and technology in recent years. Using advanced technology to develop mobile learning resources, environment and services, mobile learning provide convenience and support for learning. It enables learners to learn anytime and anywhere with mobile intelligent terminals.

As an effective way to cultivate innovative talents, academic competition has the innovative education function which can not be obtained from the conventional theory teaching and experimental teaching. Academic competition plays a unique and irreplaceable role in cultivating students' innovative mind, practical ability and comprehensive quality. The competition training based on M-learning has great potential and value, which will inevitably bring about the reform and innovation of competition training mode. Therefore, it is particularly important to explore "Internet plus" blended learning in competition training based on $\mathrm{M}$ learning.

\section{ANALYSIS FOR SITUATION OF COMPETITION TRAINING}

Competition is a kind of mass discipline activity. It is mainly based on the subject of the students. Through the implementation of independent learning and innovative design, students complete the design task. The competition conforms to the idea of innovation education in the form or the content and so on. Some knowledge points involved exceed the content of the textbook is required. A lot of competition problems are combined with engineering practice. This cultivates students' ability of integrating theory with practice, analyzing problems and solving problems, so that students innovative consciousness and ability are greatly improved.

However, the beneficiaries of academic competitions are always minority groups. This is because, on the one hand, the funding for academic competitions is huge. On the other hand, the evaluation of colleges and universities depends more on scientific research indicators, so teachers pay more attention to scientific research than teaching, fewer teachers engage in academic competitions.

Many studies combinate competition with courcing teaching, trying to benefit more students. Taking corresponding competition as the guide, the competition knowledge points are integrated into the teaching, and the competition project is designed in the teaching case, the teaching process is simulated the competition process. But the results are not ideal. Due to different degree of student acceptance, the curriculum design based on teacher teaching is still unable to achieve its due effect, though the curriculum setup by the combination of curriculum and competition has aroused the enthusiasm of most students. Therefore, it is need to transform the teachers teaching into students learning. On the other hand, all kinds of related instruments and equipments used in class are limited to classroom teaching, which can not let students continue learning and using outside classroom, and opening up of the laboratory can only solve a certain degree of problems, but can not repalced teacher's guides, and can not meet the needs of students after class learning. The development and utilization of M-learning just make up for this defect. 


\section{THEORETICAL BASIS}

\section{A. Blended Learning}

Blended Learning is a combination of traditional "face-toface-learning" and novel "online learning", such as electronic learning (E-Learning for short), M-Learning. Through Blended Learning, not only teachers can play a leading role, but also learners, as the main body of the learning process, can enhance initiative, enthusiasm and creativity, realizate individuality study [1]. Generally speaking, traditional face-to-face-learning is the classroom teaching mode, which gives the first place to teachers teaching. While E-Learning, M-Learning are relatively new modes of learning, which gives the first place to students learning. Research Report issued by Ministry of Education of United States in 2009 pointed out, compared with pure classroom teaching or remote online learning, blended learning is one of the most effective ways of learning. NMC(The new media consortium) Horizon Report: 2016 Higher Education Edition points out that the widespread application of blended learning will be one of the short-term trends that are likely to affect the transformation of higher education in the next 1 2 years [2]. NMC Horizon Report: 2017 Higher Education Edition states blended Learning is a significent technology to promote higher education in the next 1 2 years [3].

Domestic and foreign research show that blended learning is more and more used in different levels and different subjects teaching [4-5]. In terms of implementation for blended learning, most research are with the help of online learning, such as E-learning, M-learning, WeChat learning, MOOC (Massive Open Online Courses) and ICT (information and communication technology). The main research has been done for as the follows aspects: the blended learning environment construction, teaching strategies and learning strategies for blended learning, design and implementation of blended learning, the assessment for blended learning [6].

Blended learning is a mixture of teaching models based on constructivism, behaviorism, and cognitive theory. The main form of blended learning is the mixture of traditional face-toface learning and online learning, and the mixture of teacher's teaching and students' learning. On the basis of the integration of resources as much as possible to a platform, such as the careful development of online courses, lively face-to-face teaching, sharing experience and comprehensive data accumulation, blended learning establishs a one-stop learning. This makes knowledge Explication, digitalization and internalization.

\section{B. Task Driven Teaching}

Task driven teaching is a teaching method. Its essence is to arouse learners' learning motivation through tasks [7]. Based on the teaching objectives, in accordance with gradual principle, the concept, principles and skill of subject knowledge are integrated into a learning task. This makes students understand what to do, thus can promote the participation of students. Solving the problem and completing the task are the main teaching activities throughout the teaching process. On this account, students can obtain knowledge and ability, and cultivate the ability of independent research, practice, and thinking during finishing the task.

In task driven teaching, the kind of knowledge understood and grasped by students include declarative knowledge, procedural knowledge and strategic knowledge. Through the completion of the task, learners can achieve effective migration. Modern cognitive psychology research shows that different representation of knowledge in the human brain is different, the required learning methods and learning environment are not the same. In the process of learning to complete task, students need to have visual and auditory information media and different transfer mode of the support. However blended learning can represent above knowledge types well. Using realistic and virtual information transmission channels blended learning facilitate effective learning, minimize the price and maximize the benefits in task driven teaching.

\section{IMPLEMENTATION OF COMPETITION TRAINING BASED ON BLENDED LEARNING}

In this study, competiton training is combined with curriculum, a competition training based on blended learning adopting task driving teaching is proposed and designed. Blended learning involved is carried out in three stages: "before class", "in class" and "after class". The three stage blended learning implementation process is as follows.

\section{A. Before Class}

Before the formal implementation of blended teaching, the teachers need to collect the problems and experience in the competition, design the independent autonomous learning task list. Then the teachers need to make the online supporting course resources with micro video as the core to the learning platform. Autonomous learning tasks can be divided into the following four parts.

- learning objectives: curriculum and teaching objectives can provide relevant information for students in this part, such as the content of the teaching objectives, learning difficulty, proposed method and task objective.

- micro-lectures: related supporting resources such as videos, PPT, animation and micro applications is clearly required watching by students, which is complete with the teaching difficulties related to learning tasks;

- task design report, according to the specific task, through the M-learning, students should team up first, and then need to complete formulation design report about the task according to one'own imagination.

- confused the suggestion part: in the process learning students will meet with puzzle. The questions can be ask to teacher through WeChat, Q group or other instant messaging tools. teachers can grasp autonomous learning situation of students before class, and understanding the students' problems. This can make teacher carry out targeted solutions and guidance online and offline. 


\section{B. In Class}

First, teachers can adopt centralized teaching or group discussing focus on students' common problems in the process of task completion. Then, teachers can adopt individual guidance to answer questions and discuss the design reports with correspondent group. At last, a display and experience exchange will be arranged when the task is completed.

In the course of discussion, the students have already got a certain understanding of what they need to learn in the course of task interaction, and they have realized the internalization of knowledge in a certain degree. So the discussion in the classroom shouldn't spend too much time in the review, and this is different from traditional classroom teaching. In inquiry stage of the task, according to different inquiry problems, students can use independent inquiry or cooperative learning way to carry out research learning activities. In the process of guiding student to independently explore research learning, teachers should respect the independence of individual students, let students construct their own knowledge system in the process of self inquiry freely. Also teacher should ensure in the limited time to help students achieve greater learning efficiency.

In guiding cooperative learning activities, teachers should not only give students knowledge and skills. But more importantly, teachers should mobilize the enthusiasm and initiative of students' participation, through invoking some methods like brainstorming or world coffee shop. At the same time, teachers should instruct the students the method of cooperative learning activities, and provide the appropriate decision support service to protect task successfully developed.

During the design report discussion stage, teachers will discuss the design report with the students, analyze the advantages and disadvantages, and give views and suggestions. Students will revise the design reprot again. Once the design report is determined, the task begins. If there is any question, teachers will give the suggestion

After the independent inquiry or task activities are finished, a achievement display and experience exchange will be arranged. In this process, students can show the results of research learning through the exhibition of works, limited lectures, debates and other forms, and share learning experience and experience. In this process, teachers should not only review students' learning achievement, but also guide the students to reflect and summarize the learning process, learning attitude, learning experience, learning methods, and construction of self consciousness.

\section{After Class}

Students can reserve Laboratory for extracurricular study or continue to complete the task. After the presentation and communication in the class, the students modify and refine their learning results, submit their reflection and to the learning platform according to the suggestions of the teachers and other students. This can be an important part of the process of learning evaluation. On the other hand, it can also be transformed into reusable, renewable resources and education reform of culture of learning resources, to promote the blended competiton training system into a spiral of "super cycle" and self-organizing system. Also students and teachers need to exchange and evaluate the teaching and learning outcomes after the teaching activities. Students need to cooperate with the evaluation of teachers, and teachers need to make suggestions for students to improve their learning.

\section{CONCLUSION}

After two semesters of teaching practice about smart car competition shows that training mode based on the concept of blended learning improves the students' learning interest, improves students' ability of cooperation and communication, and cultivates students' practical ability and innovation ability. Blended learning, as a continuing innovation of classroom teaching, can provide more than existing education and can provide a broader space for the development of teachers' teaching.

\section{ACKNOWLEDGMENT}

This work is supported by the Guangzhou Education Science Planning Project under Grant 1201552977.

\section{REFERENCES}

[1] H. Kehang. "New development of educational technology theory from Blending Learning," E-education Research, vol. 3, pp.1-6, 2004. (In Chinese)

[2] L. Johnson, B.Adams, S., Cummins, M. et al. NMC Horizon Report: 2016 Higher Education Edition. Austin, Texas: The New Media Consortium.2016

[3] S. Adams Becker, M. Cummins,A. Davis, et al. NMC Horizon Report: 2017 Higher Education Edition. Austin, Texas: The New Media Consortium. 2017

[4] Nurcan Alkıș, Tugba Taskaya Temizel. The Impact of Motivation and Personality on Academic Performance in Online and Blended Learning Environments. Educational Technology \& Society, 2017.

[5] Auster C J. Blended Learning as a Potentially Winning Combination of Face-to-Face and Online Learning: An Exploratory Study.[J]. Teaching Sociology, vol.44 ,pp.39-48, 2016.

[6] M. Zhiqiang, K. Lili, Z. Ning,J. "Hotspots and Trends of Domestic and International Blended Learning Research_—Based on the Comparison of SSCI and CSSCI Papers Between 2005 and 2015" Modern Distance Education, vol. 6, pp.49-57, 2015. (In Chinese)

[7] Y. Shuihe. "Internet plus" the integration of Vocational Accounting Teaching. Chinese Vocational and Technical Education, vol. 14, pp.3033, 2017. (In Chinese) 